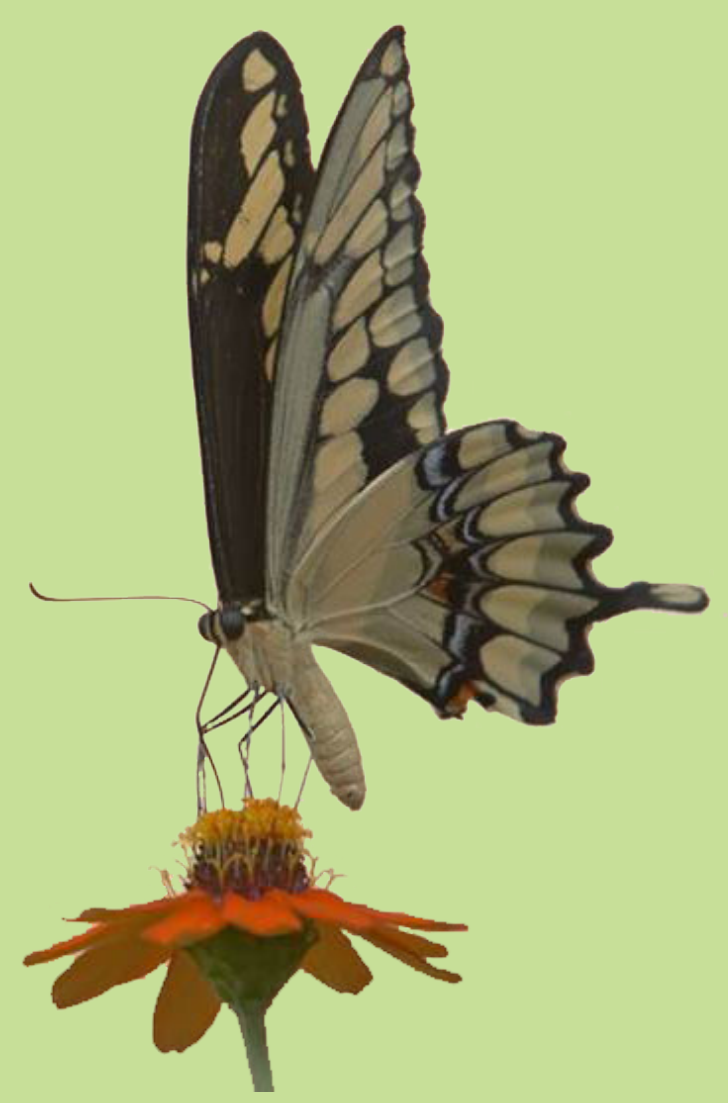

\title{
Mean and Variance and Their Changes in Economic Development
}

\author{
ERICH W. STREISSLER
}

KIOES Opinions 2 (2014)

KIOES Opinions are published by the Commission for Interdisciplinary Ecological Studies (KIOES) of the Austrian Academy of Sciences (ÖAW). KIOES publishes current opinions of its members and staff related to topical subjects on an irregular basis in KIOES Opinions. The target audience includes scientists, policy makers and the public. Opinions expressed in this article are solely those of the author, and they do not necessarily reflect in any way those of KIOES or ÖAW. 


\section{Mean and Variance and Their Changes in Economic Development}

\author{
ERICH W. STREISSLER * \\ * Austrian Academy of Sciences \\ Dr. Ignaz-Seipel Platz 2, 1010 Vienna
}

Received: 25.03.2014, published online: 01.04.2014

\begin{abstract}
Erich W. Streissler was born in Vienna, Austria, graduated as Dr. iur. from Vienna Law School and is now Professor Emeritus of Economics, Econometrics and Economic history at the University of Vienna. He was distinguished Austrian Visiting Professor at Stanford University and frequently at Oxford University. He is a member of the Bavarian, the Hungarian and the Austrian Academy of Sciences.
\end{abstract}

\section{I}

This paper deals with a specific aspect of a specific probability distribution, namely with changes over time in the distribution of macroeconomic growth rates, in other words: with the changes in the distribution of percentage changes in national income. The "normal" probability distribution is fully defined by two parameters: its mean or first mathematical moment and its variance or second moment. At present the empirical distribution of national income percentage changes actually differs slightly from a "normal" distribution, in three ways: (1) its third and central mathematical moment, i.e. the expected value of the third power of the random variable in question, is not quite zero, the distribution being "flatter" than normal; (2) it is not quite symmetrical in change, upward changes being on average slightly bigger than downward ones; (3) and above all, probability distributions shift over time in their means and even more so in their variances. The last point is especially controversial: In 1953, Milton Friedman ${ }^{1}$ explicitly declared that the mean - he ignored the variance - of the probability distribution of logarithmic income changes had been constant over time since the Industrial Revolution, a statement difficult to disprove empirically, because the English data from the 225 years since about 1790 have been too few to dis-

1 Milton Friedman, "The Case for Flexible Exchange Rates" in M.Friedman, Essays in Positive Economics, Chicago and London 1953, 157-203. Especially in IIA3, "Speculation in foreign exchange markets will be stabilizing", Friedman argues the exact opposite of that caption. prove Friedman once for all. On the whole, constant probability distributions over time would be more typical for many phenomena in the natural sciences.

At the end of March 1968, I focussed my inaugural lecture in Vienna on the question of the significance of looking on the one hand at the mean and on the other on the variance measures of economic data. ${ }^{2} \mathrm{~A}$ didactic simplification was my statement that economic analysis was (only) looking at mean values of economic growth while statistical analysis tended to look (mainly) at variances - especially at the variance in economic growth rates, both over time and, actually closely related, between growth rates of different economic indicators and over different places. As to differences of mean rates of growth over time I pointed out that in Austria these differences (and the deeper reasons for them) were quite distinct for the 1940s, the booming 1950s and the already declining 1960s. In contrast to Friedman, I spoke about changing probability distributions of growth over time.

The variance of economic growth rates seemed to be increasing then, especially in the difficult late 1960s. Remember I was speaking just before a then imminent political economy crash, especially a crash of academic life, which began in May 68 in France.

2 Erich W. Streissler, "Structural Economic Thought - On the Significance of the Austrian School Today (Inaugural Lecture Part I), Zeitschrift für Nationalökonomie 29, 1969, 237-266; "A Stochastic Model of International Reserve Requirements During Growth of World Trade (Inaugural Lecture Part II), Zeitschrift für Nationalökonomie 29, 1969, 347-370. 
II

The contrasts between mean economic development and its variances both over time and space have been of central importance in recent years - worldwide. Their driving force, American investment activities since the year 2000, in particular that of banks, peaked just before the crash of early autumn 2008, on some measures the greatest economic crash ever. ${ }^{3}$ After the secular boom years 1995-1998 economic growth started to dwindle, even to stall, from 2000 onwards. I pointed this out already at a conference of the Austrian National Bank in 2001, ${ }^{4}$ only to be vehemently contradicted by a US-American lady economist present. It was the political hope of the USA that a sharp decline of growth rates could be prevented. The central feature, however, was that the economic growth rate in the USA turned markedly down while at the same time the variance of sectoral growth went up considerably - once more the feature of change in both mean and variance of growth simultaneously. But it is just this increase in variance that makes it particularly difficult to see any decrease in growth and, above all, to perceive the precise amount of the decline.

The level of banking activities had about doubled since the 1990s, especially in the USA but also in Great Britain (and Ireland). Again and again, up till now (the $15^{\text {th }}$ year of decline!) standard bank propaganda has tried to persuade the public that financial returns are good, if not increasing, snatching at the few moments of temporarily higher rates of return for advertising effects. Remember: economic growth measurements are very uncertain at the best of times! Such moments of seemingly higher returns do occur because of a greater temporal variance of the rates of return. Bank propaganda to buy financial assets was focussed - erroneously - especially on equities although, in fact, longer-term averages of rates of return had declined most. But the sale of equities would earn the banks the highest fees, relative to their other business.

3 See a statement of Ben Bernanke, discussed in detail in section VI of this paper.

4 E.W.Streissler, "Financial Institutions and Technological Progress: An Historical Perspective", Oesterreichische Nationalbank, Volkswirtschaftliche Tagung 2001, 2-10. See also "The Financial Market Crisis", Lecture, Gesamtsitzung der ÖAW, January 17, 2009
III

The confusion between actually only short-term and only apparently high rates of economic return of financial institutions (like banks) and the secularly declining average rates of economic growth and consequently falling real rates of return is not unusual in periods of sharply declining economic development. In fact, it is typical of turning points of economic growth rates. It had been a feature of the immediate post-Napoleonic era in Europe and once more in Vienna of the crash of May 1873, when a seemingly soaring development during a world trade fair turned into secular depression almost over night, appropriately marked by a frightening outbreak of cholera. The most immediate and relevant example of such a significant turning point in development was, of course, the "Great Crash" in the USA from October 1929 to spring 1933 . The significant difference to the present was that this time the switch "point" in development was very much extended in time by both fiscal and above all monetary activism in the USA due in particular to the politically motivated initiatives of the governor of the Federal Reserve, Alan Greenspan - an extension which, of course, made the eventual crash only greater.

In the last quarter of the $20^{\text {th }}$ century the size of the banking sector both in the USA and Britain had about doubled; but especially in the US very little innovatory manufacturing seemed to be left. The US banking industry simply refused to admit that any significant change in growth rates was taking place. Over the past 25 years, in the USA any longer term income growth was concentrated in the top fifth of the income distribution, especially in the top $1 \%$, while average and below average incomes actually declined. The income distribution of the USA has become ever more unequal. ${ }^{5}$ The top tenth comprises mainly banking incomes, of course, and so the political denial of decline is an upper class phenomenon, particularly evident among Republicans.

"America's material standard of living continues [!] to improve", ${ }^{6}$ Alan Greenspan wrote at a time (late 2007) when correctly calculated it was already noticeably declining for most Americans. In mid-October 1996

5 The increasing variance of growth rates of individual incomes in the USA will be discussed in section VII below.

6 Alan Greenspan, The Age of Turbulence - Adventures in a New World, London and New York 2007, 181. (To be quoted as Greenspan 2007.) 
Greenspan coined the term "irrational exuberance": It was typical of top income earners and due to the (positive) effects of inflation on financial asset values and thus of inflationary improvements even of real wealth. Remember: Inflationary income and wealth increases are real for those rich enough to spend only a very small part of their current income on consumption. Greenspan, the outstanding US central bank governor (governor for more than 18 years: from the summer of 1987 till very early 2006) was decisive in boosting the erroneous US belief in continuous "improvement". More and more, he turned from calling exuberance "irrational" to actually himself stimulating this exuberance, both for political reasons and from a personal optimism due to a belated joyful marriage. His autobiography of 2007, written at the age of 81 , is subtitled "adventures in a new world".

\section{IV}

What were the preconditions of the $21^{\text {st }}$ century developed world, in particular of US development during the decade of the 1990s, if not already the two decades of the 1980s and the 1990s? Centred on the years 1994-1999 the integrated developed economies experienced their fifth Kondratieff boom since about 1785. In 1939, in a weighty publication ${ }^{8}$ on business cycles of various lengths Joseph Schumpeter named the longest cycles (of 40 and more years) after their Russian discoverer, the statistician Kondratieff. Kondratieff booms are concentrations in time of major innovations in the course of historical development, such booms of several years' length typically being followed by long recessionary periods, as now during the first and second decade of the $21^{\text {st }}$ century.

While the first Kondratieff boom in Britain after 1785 centred on two industries, cotton goods and steel production, and later booms on a variety of industries, the boom of 1994 to 1999 was unusually narrowly based, centring on one industry only, viz. on computer hard and soft ware. Furthermore, while in earlier times these leading boom industries had typically employed so-called capital using technologies, e.g. railway construction during the second Kondratieff of the mid $19^{\text {th }}$ century, now the computer industry was typical of the opposite development: This

7 Greenspan 2007, 176.

8 Joseph Schumpeter, Business Cycles. A Theoretical, Historical and Statistical Analysis of the Capitalist Process, 2 vols., 1939. industry was strongly capital saving. Therefore there was no long-term follow-up of investment due to longer time higher returns for computer production or computer using firms. Not the innovative producers themselves profited largely, but much rather the final consumers, in terms of much reduced computer prices. The boom was therefore unusually short. Already in 2000 we witnessed the first computer industry crash in the so-called dot-com crisis, with the spectacular crash of ENRON in December of that year. This rapid change from particularly high economic growth rates to very low, or soon negative, growth rates - and that with an increasing variance of different growth rates - made for a substantial problem of general understanding, especially of fast understanding by the banks financing those developments. A recent issue of The Economist drily states what happens again and again: "It took barely a month for the bubble of optimism that formed ... at the start of the year to subside". 9

The difficulties of understanding were aggravated by the fact that the boom of the latter 1990s had been also inflationary, to a considerable extent, making for especially high nominal rates of return, while the first and second decade of the $21^{\text {st }}$ century showed rapidly dwindling rates of inflation, and in a number of countries, particularly in Europe and Japan, even declining price levels. The booming late 1990s were followed by an ever more recessionary first decade of the $21^{\text {st }}$ century. The rapidly worsening investment climate created a false optimism not only on the part of those banks that were directly financing industrial innovations, but also of banks that did so only indirectly.

\section{V}

Let us turn to a specific feature of US-American development: namely to the behaviour of the average American private saver, who felt himself stimulated by expansive public policy decisions and in particular by the economic policy of Alan Greenspan from 2001 onwards.

The average American saver looked less and less at his income as the determinant of his savings, but rather at his wealth. And wealth in the USA increasingly meant average stock prices. This was due to the fact that in the last quarter of the $20^{\text {th }}$ century the share of

9 The Economist, February 15, 2014, 59. 
stock-owners in the population went up from about one third to fully two thirds, thus making stock ownership more or less the rule rather than the exception. As Allen and Gale noted in an important 1994 article: ${ }^{10}$ For the average investor, holding on average only different shares or share indices, share ownership was not at all diversified, but often it included artificially created financial media tracking the movement of averages of share prices (index accounts).

Once more it was Greenspan who, during his long tenure at the Fed, had also switched orientation of the Fed's policy more and more away from incomes and towards stock market asset values. From 1994 to 1999 stock prices first went up due to the fifth Kondratieff boom in rising incomes that raised stock market prices on average by a factor of three. Then, from 2003 to 2007, they soared because of the increasing asset price effect of falling interest rates. Thus, the average American had felt himself first richer due to a stock market boom and then due to the positive asset price effect of falling interest rates - which entailed rising house prices. Secularly falling interest rates often "materialized" as rising asset values.

Compared with Germany and Austria whose savings rates were around $10 \%$ of GDP, US American savings rates were unusual as they progressively fell to close to zero. In 2005-2007, the rate of private personal savings actually fell to $-2 \%$. Americans believed that rising nominal asset prices - first in terms of stock prices and then in terms of house prices - spelled a sufficient increase in wealth, without additional real savings being needed. And also, since the Regan administration, Americans have tended to believe that rising current account deficits do not matter: The whole world would gladly continue to lend to the USA. Or, as once more Alan Greenspan said, quite in contrast to what would hold in Europe: "The current account deficit is the least of my cares". He only thought about "long-term growth and employment"11 and rarely looked at long-term interest rates and never at the current account. On March 29, 2008 ${ }^{12}$ the US current account deficit reached 739 billion dollar or $4.7 \%$ of the GDP and the trade deficit 819 billion. Having shrunk only a little in the 2008-2009 depres-

\footnotetext{
10 Franklin Allen and Douglas Gale, "Limited Market Participation and Volatility of Asset Prices", American Economic Review 84/4, 1994, 933-955.

11 Greenspan 2007, 110.

12 The Economist of that date.
}

sion, the current account deficit still stood at 399 billion in mid-February $2014,{ }^{13}$ and the increase in debt was larger than the growth in US incomes.

\section{VI}

Obviously all this had to do with US monetary policy, especially that of Greenspan. Actually it had already been Clinton, president from 1993 to 2001, who had decided to make a political effort to get as many Americans as possible to be owners of their homes. This campaign was continued under Bush II. In essence it meant getting US banks to lend to new home buyers most or even all of the purchase price, soon asking initial mortgagees to contribute on purchase no more than $3 \%$ and finally, around 2005 , to contribute in fact zero of the purchase price! "By 2006, nearly $69 \%$ of households owned their own home, up from $64 \%$ in 1994 and $44 \%$ in $1940 "{ }^{14}$ On the whole, stimulating the economy by huge government and government-guaranteed private debt was the traditional remedy when the real economic boom of the fifth Kondratieff petered off at the turn of the millenium. The price increase in houses eventually turned into a price fall, but the banks still believed - wrongly now - that they could lend well over $100 \%$ of the purchase prices of houses.

For the Republican Greenspan, stimulation was also to a large extent politically motivated: After the Democratic Clinton administration at last a Republican was elected president, G.W. Bush. Most unfortunately, however, two months after his taking office a major recession began in the USA in March 2001. It had been predated by the computer industry recession of the "dot.com crash" of the year before. In 2001 Greenspan stimulated as much as he could: He lowered the Federal Reserve short term interest rate from $6.5 \%$ to $1.75 \%$ already during 2001 and later, from 2002 to 2004 , to only $1 \%$ - an interest level low last reached in the 1950s. (After the crash of 2008 this policy of extremely low short-term interest rates was continued, even more markedly, by Greenspan's successor, Ben Bernanke, who set the short-term interest rate at next to zero, viz. to $0.2-0.25 \%$. There the Fed rate still stands, even today (March 2014).

The 9/11 attack on New York and Washington was a sort of windfall for Bush II, a president oriented more

\footnotetext{
13 The Economist, February 15, 2014

14 Greenspan 2007, 230.
} 
towards fiscal policy: American citizens, already then very low savers, rallied to the President's appeal that higher private personal spending was a patriotic duty, and the recession (in the US sense of falling national income) ended after only eight months, by November 2001. As Greenspan proudly relates, ${ }^{15}$ this together with government tax cuts brought Bush II an approval rate of $86 \%$ in late autumn of 2001 .

The stimulating effect of a highly expansive fiscal policy together with Greenspan's policy of very low interest rates assured the re-election of Bush in 2004. Before the excesses of overstimulation of the US economy became evident in 2007 and 2008, Greenspan resigned as governor of the Federal Reserve at the end of January 2006, two and a half years before his appointment would have run out (viz. in mid-2008). He resigned with the specious argument that he was about to turn eighty. Considering that the economy was then still running smoothly, one wonders if the great policy optimist Greenspan was then following his own prescription in his quasi-valedictory paper of 2004: namely that, in policy decisions, one should always take into account the small probability of an alternatively very bad outcome of one's policy as well. ${ }^{16}$

\section{VII}

The early $21^{\text {st }}$ century was the first time since the immediate post-war era that economic development was characterized by huge variances: the variance of investment shares relative to GDP, the variance of savings shares, similarly defined, and most interestingly the variance of the difference between investment and saving shares - or, what is by definition the same thing, the difference of export and import shares in GDP.

At the height of the US housing boom the variance of current accounts stood at a maximum. ${ }^{17}$ The US current account deficit stood at $4.7 \%$ of GDP, surpassed in relative deficits only by Greece $(-12.0 \%)$, Spain (-9.1), South Africa (-8.0), Turkey (-7.7), Pakistan (-7.0) and a little bit by Australia (-5.6) and Brazil (-4.9). On the other hand, current account surpluses above $10 \%$ of GDP were achieved by Sin-

\footnotetext{
15 Greenspan 2007, 6.

16 Alan Greenspan, "Risk and Uncertainty in Monetary Policy", American Economic Review, PP, 94/2, 2004, 33-40.

17 The Economist, March 29, 2008.
}

gapore (23.5\%), Saudi Arabia (22.8), Norway (15.8), Switzerland (14.6), Malaysia (13.9), and China (10.4). In absolute terms, the US current account deficit of gigantic 739.6 billion was nearly exactly financed to about one third each by the surpluses of Germany and Austria (267.6 billion), of China (249.9 billion) and of Japan (214.7 billion).

At the nadir of the recession around mid-2010 nearly all the figures had shrunk so that the variance had declined sharply, though, in historical comparison, it was still very large. The US current account deficit had nearly halved to 391.9 billion or only $-3.1 \%$ of GDP, ${ }^{18}$ while China's surplus, absolutely somewhat larger and relatively to the US twice its former level, stood at more than $70 \%$ of the US deficit at 282.2 billion, then only $4.2 \%$ of Chinese GDP. With 191.3 billion Germany and Austria were financing about $40 \%$ of the US current account deficit. No current account deficit stood at 7\% or more of GDP, while in the 2008 statistics five countries had exceeded that level. The relative current account surpluses had also nearly halved, Norway standing - exceptionally - relatively a little higher at $16.3 \%$, while Singapore had $14.1 \%$, Malaysia $13.3 \%$, and Saudi Arabia $12.2 \%$ of their GDPs as surpluses. All other positive current account balances remained well below $10 \%$ of their GDP levels.

If we now switch to the present, ${ }^{19}$ the variance of current account balances is once more substantially smaller, although still historically high. Contrary to the present celebratory mood in the USA, the US current account deficit is at 398.7 billion absolutely about as high as 2010 , but relatively now only $-2.4 \%$ of GDP. In the periods in between, the deficit in current account figures usually had been even higher than around 450 billion. China is still financing nearly one half of the US deficit, 388.6 billion, which now equals only $1.9 \%$ of its own GDP. At 276.2 billion Germany plus Austria had greatly increased financing foreign both in absolute and relative terms, financing nearly $70 \%$ of the US current account deficit, the same percentage as China in 2010. Both current account surpluses and deficits tended to be smaller in relative terms. But four northern and central European countries outside the EU together financed as much as China: Denmark, Norway, Sweden, and Switzerland had a current account surplus

18 The Economist, August 14, 2010.

19 Figures are from The Economist of February 15, 2014. 
of together 199.1 billion. Five countries achieved a relative current account surplus larger than $10 \%$ of GDP: Singapore $+20.4 \%$, Saudi Arabia +18.0 , Norway +12.8 , Switzerland +11.8 and Taiwan, which had increased its surplus to $+10.8 \%$. More than $6 \%$ deficits in the current account only occur twice, for South Africa $-6.6 \%$ and the relatively largest deficit for Turkey at $-7.5 \%$.

The USA showed a current account deficit in 32 out of the 33 years from 1982 to 2014 . The sole exception was 1991, when the US fought Iraq with so many allies that those allies largely financed the war; thus the USA came out of it with a positive current account. Usually it was the US federal budget that was in a huge deficit, but also, and progressively so, the failing of US private personal savings, which reached an exceptional -2\% of GDP in 2005-2007. In the last years of the Clinton administration the exceptional happened: From 1998 to a maximum in Clinton's last year, 2000, there was no longer any government budget deficit, and the still remaining current account deficit was due only to the shortfall of private savings relative to the then still relatively high investments. After the default of Lehman Brothers on September 15,2008 , government deficits as the causes of current account deficits exploded. In the last years of Bush II and above all in Obama's first presidential term the US budget deficit rapidly doubled government debt - to Portuguese levels of about $112 \%$ of GDP. So far there is no sign that US budgetary indebtedness will shrink. The USA seem to be unaware that increasing international indebtedness is dangerous.

\section{VIII}

Worldwide, the financial crash of 2008 was the largest ever, in absolute and possibly even in relative terms. And it was, as in 1929-1933, largely a US affair, but with strong reverberations in Europe and even in the emerging economies. This time it was Europe, particularly the largest European banks that above all financed US excesses. In 1929 to 1933, already before the peak of the boom, the USA had withdrawn finances from Europe due to the then high returns on their own stock market.

After 2001, the first signs of serious financial difficulties showed up in mid-2007, and March 2008 witnessed the first failure of an important US financial firm, Bear Sterns. Upon government intervention and with considerable financial help by the govern- ment Bear Sterns was bought by several other large banks. This led to the erroneous belief that the US government would always lend a helping hand to big firms in financial difficulties.

In early September 2008, the two governmental mortgage guaranteeing agencies (then actually privately owned) Fannie Mae and Freddie Mac had to be bailed out by the government at a seriously high level. The central financial problem was that, driven by government, US banks had lent more and more recklessly to poorer and poorer private individuals. They had lent in terms of mortgages, from which, however, the sales agents were the only ones who profited: In many cases, buyers of private houses did not even pay back the first instalment of their mortgage and as they did not have to make any down payment on purchase, house price inclusive of all sales fees being credited, penniless buyers could actually just live about one year in their newly bought house for free before being evicted, in the end having paid nothing at all. For by US law contrary to European law, US debtors only lose their mortgaged property, but nothing else.

In the very last years of that government-stimulated boom house prices had started to rise markedly, altogether by about $25 \%$. (Similar and even higher increases occurred in Europe, though very little in Germany and Austria.) On a mortgage including sales fee therefore typical house values eventually lost up to $50 \%$, as house prices soon dropped to about two thirds of their normal level, and even more relative to their inflated sales values including sales agents' fees. About half of the banks' losses were due to such foolhardy mortgages, the other half to losses on complicated (non-transparent) financial contracts. Greenspan estimated that the entire world lost about $\$ 40$ "trillion" US dollars on illusory house prices and the USA $\$ 17$ "trillion" or about $120 \%$ of GDP. But asset prices fluctuate much more over time than incomes. So it is possible that optimistic US estimations can figure the losses at substantially less, i.e. at 40 or $50 \%$.

On Monday, September 15, 2008, at 1:45 a.m., the decisive crash occurred when Lehman Brothers, the fifth largest US financial firm had to announce its bankruptcy. The US government had first tried to get South Korea to help Lehman Brothers, but to no avail. Then the huge British bank, Barclays, had been approached. Barclays was more or less willing to step in, but was strictly forbidden to do so by the British 
Chancellor of the Exchequer, Darling, who argued that it was likely to take decades for Barclays' to be paid back. The popular song "Do not forsake me, oh my darling" acquired new connotations then! Darling simply said No. Thus, the time-honoured tenet that the largest financial companies were too important and too large to fail was proved wrong: Lehman Brothers was too large not to fail, too large to be saved by the US government.

The shock in the USA was enormous. Now, where was a financial firm that was not in danger? So that when on the next day, September 16, the only slightly smaller insurance company, AIG, was on the point of failure, government did step in, giving guarantees even to all stock holders and not only to the creditors of AIG. It could be argued that after the Lehman Brothers failure such government action was necessary to calm the markets, especially the foreign markets, as AIG was financed to more than half by foreigners. What was not remarked upon, however, not even in the text of the important financial report of a bipartisan commission of the US Senate ${ }^{20}$ was this: The largest shareholder in AIG, holding 14\% or nominally $\$ 1.1$ billion, was Goldman Sachs; and the casting voice in that decision was that of the Secretary of the Treasury, Nick Paulsen, who happened to be a former partner of Goldman Sachs. The same was true of the head of the New York stock exchange, Tim Geithner, who was to succeed Paulsen as Secretary of the Treasury under the next President. So Goldman Sachs was saved by the fortunate coincidence that the financial branch of the government was in the hands of former Goldman Sachs partners. - At present, Goldman Sachs, with around 11\% annual return on its capital, is once more the best earner among the big banks. ${ }^{21}$

In what followed, the US government helped, each time in different ways, one big financial firm after another. The biggest bank, Citibank, was largely nationalized in 2009. By now, however, most of the financial firms that had been assisted by huge sums of public money (remember the vast fiscal indebtedness entailed), especially under the Obama administration and under Geithner, can stand on their own feet again.

20 The Financial Crisis Report to the US Senate by 10 Senators (6 Democrats, 4 Republicans), published in January 2011 ( a mimeographed volume of more than 600 pages).

21 The Economist, February 19, 2014, 62
IX

Speaking of public money or public assistance, I must point out a serious ethical problem: Public money is the sovereign's money. The problem is at least 2000 years old, going back to the times of the first integrated world empire, the Roman empire. Should public finance both cost and serve the sovereign or rather a special interest group? This question was put to Jesus by the Pharisees - a special interest group interested in public finance only in so far as it would furnish the Temple. Taking the Roman tax coin, the denarius, as evidence, Jesus answered: "Pay Caesar what belongs to Caesar - and God what belongs to God" (Mt 22,15-22, Mk12,13-17, Lk 20, 20-26). God not being considered financially relevant, "Caesar" was the sovereign. In a democracy the sovereign is the general public or in financial terms the average taxpayer. $\mathrm{He}$ or she should be the focus of all financial decisions.

But that was not what the US Secretary of the Treasury, Tim Geithner, under Obama considered relevant. For the USA he took only a much smaller group with very special interests to be relevant: Every aspect of crisis resolution was to be geared to the interest of the financial community; or to put it in everyday language: geared to the special interest of banks and bank owners. From 2008 to 2014, the USA financed bankers mainly out of public funds. Similarly in Europe, particularly in Spain, the debts of large banks and their owners had to be financed by the general public.

\section{$\mathrm{X}$}

The most important difference between development forecasts in the natural sciences, where the natural phenomena examined have no "voice", and the actors in finance and monetary economics is the large number of self-declared "experts". In many cases, these "experts" have a personal interest in the effect of their development forecasts. They are highly interested in an economically "good" outcome of development because that means that their asset prices will go up and they become richer. US Americans who are dominated by their banks more than people in other economies, tend most strongly to overestimate the returns to their financial development and perhaps also to underestimate the rate of development of other economies. Alan Greenspan's biography is a fascinating example of such US American self-deception. Even after the great depression of 2008-2009 the standard 
US longer time view remained astonishingly bullish in spite of the fact that not before 2013 did US national income just regain its 2008 level: What was in effect zero or negative economic growth was considered a "good" development.

This bullishness has much to do with the fact that the US income distribution is the most unequal one of all nations ${ }^{22}$ and is progressively becoming even more unequal. Within the last 30 years, only agents in the top $20 \%$ of the income distribution have registered any gains in real income, while already the median earner has lost some 2 to $3 \%$ in real income and earners in the echelons lower down have lost even more. On the other hand, young entrants into jobs in banking and finance are enviously reported to receive up to three times the initial salaries of jobholders in the "real" economy. Of course, US overvaluing optimism is partly due to the fact that the richest US income earners, those who also matter politically most, have been doing relatively best. Among US Republicans, above all white males, there is a considerable number who would even deny that there actually ever was a recession in America. They tend to think an assumed recession is part of an official economic "miscalculation".

Whether the Great Depression of 1929-1933 or the already too apologetically named "Great Recession" of 2007-2009 was the greater world event is perhaps debatable. Ben Bernanke, Greenspan's recently retired successor as Governor of the Fed (2006-2014) is on record as considering the present depression the economically greater one. The US 1929-33 depression caused the general price level to drop by some $22 \%$, while recently the deflationary effects were smaller and at most only temporary, but the breakdown in the by now much more important and larger financial markets was far more devastating. In other words: 1929-1933 was larger in "real" terms, 20072009 was financially more serious.

This is also due to the fact that now the countervailing financial activities of the Federal Reserve and all other central banks of the developed world were much more extensive and intensive: What was new is that central bank interest rates everywhere in the developed world were dropped to some $0.2-0.75 \%$ a year and have been kept there until now, i.e. by

22 Anthony R.Atkinson, Th.Pickety and E. Saez, "Top Incomes in the Long Run of History", Journal of Economic Literature 49/1, 2011, 3-71. now for the sixth year, with only the slightest signs anywhere of an "incipient end" to this hyperactivity. What has been true for the USA has in many ways been true also for the rest of the developing world and for East Asia, but in the opposite direction, this rest of the world being fully complementary to the USA.

So far, attempts at creating an upswing of the real economy have not been successful, apart from repeated periods of a very few hopeful months each. Worldwide, the common effect of stimuli in the financial sphere is a huge excess of intended savings over real investment opportunities; at best governments run up more debt and use the funds domestically, i.e. with an income multiplier of at most one, though often smaller: The multiplier in the USA of around one is among the largest. In contrast Germany was forced - illegally - by the now governor of the European Central Bank, Mario Draghi (once upon a time also at Goldman Sachs') to hand out, without interest, most of its current account surplus of $6.6 \%$ of GDP to other European economies. In fact: Germany is handing a huge gift to the recipients of such "loans". Germany' true GDP is, of course, reduced, by that amount!

\section{XI}

The crash of 2007-2009 can be seen as a change-ofvariance phenomenon: it has changed the variance of economic development, i.e. of the growth of national product. Since 2000, average rates of economic growth everywhere had already tended to decline relative to the fifth Kondratieff boom years of 1994-1999. Greenspan comments: ${ }^{23}$ "Annual growth of non-farm business output per hour has averaged close to $2.2 \%$ since [1870] ... Output per hour, ... after the large surge in growth ... peaked at $4 \% \ldots$ and slipped to a $1 \%$ rate by the first quarter of 2007 ", i.e. already before the crash. Since 2007-2009 we have witnessed not only a further decline in average growth, but also at first a jump up and then a somewhat lesser increase in the variance of growth rates, especially taken over different countries at the same time, but also (to a lesser degree) a variance increase of averages of growth rates over time.

Similar problems of variance changes occur also in other quantitative sciences, of course. In microe-

23 Greenspan 2007, 471 
conomics, in contrast to the macroeconomics of financial markets, a variance problem was attacked much earlier, in the first analysis of quantitatively incomplete information. In 1961, George Stigler, in an article that was eventually to earn him a Nobel Prize, ${ }^{24}$ was the first to analyse the question how to find the best, and that is, given the quality, the lowest price for a commodity to be bought. Finding the lowest price within a distribution of sample prices is a variance problem. Stigler suggested that given the cost functions of sampling prices and, on the other hand, a basic distribution of prices you have to find the optimal figure in the sample of price claims to be examined. The optimum in this search for the lowest price to be paid is found when the marginal cost of further sampling is at most as high as the expected difference between the relatively lowest price found and the actual lowest price possible. The sampling procedure suggested assumes, however, that you can get price information only from the whole price sample drawn; e.g. how many costly queries do you have to send out if you hope to receive all the answers back at nearly the same time. In this case given the price and cost distributions the optimum number of queries to be sent out is fully determinate. But if you receive an answer each time you ask for a selling price, the optimum search procedure is different: You have to fix in advance an acceptance price, a price when to buy without searching further. In this case the number of search steps is not given, but is itself determined by a probability distribution: A search can take a short time or be lengthy, possibly - with a tiny chance - even reaching infinity. Even for these slightly different cases of optimal search the search procedures are thus already different; and nothing at all is as yet said about how to find the underlying price distribution, so that optimum price search is already a highly complex phenomenon.

In some periods of pictorial art, there is what one might call a surfeit of "great" painters, while at other times there are very few top artists - again a variance phenomenon. In some natural sciences another type of variance phenomenon has become central. Important investigations in physics show path-breaking interest in phenomena as close as possible to near absolute zero temperatures or, on the other hand, at extremely high temperatures. Looking at extremes in

24 His Nobel prize winning article is G.J. Stigler, "The Economics of Information", Journal of Political Economy 69, 1961, 213-225, these ways is once more a way of looking at variance phenomena of our world.

\section{XII}

The increasing heterogeneity and complexity of macroeconomic financial positions is to a large extent the cause of widespread misjudgement of US financial problems. In Greenspan's view financial "markets have become too huge, complex and fast-moving to be subject to twentieth-century supervision and regulation". ${ }^{25}$ But that financial markets are now "too huge" is not the relevant point. Not the absolute size of international financial markets is relevant, but rather that part of them that is not rapidly self-equilibrating in times of crisis. In 1970, the Nobel Laureate Eugene Fama presented a basic model ${ }^{26}$ of varying self-equilibrating mechanisms of markets, and in 2007 Greenspan held that "market failure is the rare exception"27 and that "regulation, by its nature, inhibits freedom of market action, and that freedom to act expeditiously is what rebalances markets". ${ }^{28}$ With these remarks, Greenspan only showed the usual American optimism about market behaviour before the crash of 2008. Unfortunately, market failure has proved to be not at all "rare". Since 2008, we have known that Lehman Brothers was a banking firm too large to be financially saved, that regulation can be too costly to be effected or, on the other hand, that regulation may even increase the costs of a financial crisis. At times important groups show market destabilizing behaviour and that for considerable periods of time. "Value is what people perceive it to be", says Greenspan. ${ }^{29}$ But in turbulent times such perceptions may easily be wrong and, on the other hand, the opportunities for rapidly shifting finance much too large. "Between the end of 2001 and March 2007 [Greenspan's last date is "June 2007"] China and Japan combined accumulated $\$ 1.5$ trillion of foreign exchange, of which four-fifths appears to be in dollar claims." ${ }^{30}$ Thus the value of the US dollar basically depends only on the policy of two countries (or, adding

25 Greenspan 2007, 489.

26 Eugene F. Fama, "Efficient Capital Markets: A Review of Theory and Empirical Work", Journal of Finance 25/2, 1970, 383-417.

27 Greenspan 2007, 492.

28 Greenspan 2007, 489.

29 Greenspan 2007, 486

30 Greenspan 2007, 486 
Germany, on three); and that they hold four fifths of their funds in dollars is actually a much higher share than that of the dollar among world currencies held. Even \$1.5 "trillion", however, is a tiny share of worldwide funds. Of these, Greenspan says: "Aggregate holdings of foreign exchange by central banks and world private-sector portfolios of foreign crossborder liquid assets approached $\$ 50$ "trillion" in early 2007, according to the BIS and the IMF." ${ }^{11} \$ 50$ "trillion" are more than thirty times the already huge $\$ 1.5$ trillion quoted above. Shifts in a very few big countries' willingness to hold such funds or, on the other hand, a possible stampede of relatively few holders of "private-sector portfolios" may cause huge exchange rate movements. The stability of the value of the US dollar is dangerously dependent on the "good behaviour" of governments, on the one hand, and of private speculators, on the other.

"[U]nwinding of our current account deficit is not likely to have a major impact on economic activity or employment", wrote Greenspan in 2007; and "monetary policy can simulate the gold standard stable prices". ${ }^{32}$ Both of these highly optimistic evaluations are historically obviously false. As to stable prices under the gold standard: From 1929 till early 1933 the US price level fell by a full $22 \%$, still under the gold standard. But uniquely in world history from 1945 1953 the price level of the USA doubled without low nominal interest rates changing, which, as never before in history after a major war, reduced the share of US government debt in GDP by one half. In the more than five years after the autumn of 2008 US monetary policy has been highly expansionary and yet the price level hardly rose. The US current account in absolute dollar terms about halved, but it was not "unwound". Another evidently wrong forecast by Greenspan is the following: "CPI inflation rates by 2030 will be some $4 \frac{1}{2} \%$ higher $^{\prime 33}$ (when, in fact, there will be hardly any inflation and therefore hardly any rise). A nominally halved but still gigantic US current account deficit has had no discernible effect on "economic activity or employment". Nor did near zero short-term Federal Reserve interest rates have a noticeable effect on the real economy. Altogether after the crash of September 2008, but quite contrary to Greenspan's standard line of thinking, real economic

\footnotetext{
31 Greenspan 2007, 487, note.

32 Greenspan 2007, both quotations 491.

33 Greenspan 2007, 483.
}

development seems in large part to have been decoupled from nominal economic changes.

There is potential here for serious conflicts of interest. The palpable impossibility of continued US current account deficit accumulation is clear, by all historical experience. However, in the last five years US government indebtedness has about doubled to some $112 \%$ of GDP - which is the level of Portugal! - without there being visible any tendencies or seeming desire to lower it. Since 2000 and even more markedly since 2008, there has been an obvious divergence between different nations in their positive or negative current account positions or, in other words, in their probabilities of tending to become ever more debtor or ever more international creditor nations. This has already been touched upon in section VII. But there is also a mounting potential conflict within nations and that particularly strongly within the USA. There is a dynamic of conflict due to the mounting income inequality: the richest Americans becoming ever richer on average and the lower half of the US income distribution having lost in real incomes over the last 30 years.

Thus, income distribution has rapidly become more unequal. The Gini coefficient of income inequality "rose steadily between 1980 and 2005 from .403 to $.469 " .^{34}$ Since 2008 "95\% of the gains of the recovery have flowed to the richest $1 \%$ of households". ${ }^{35}$ In fact, the top $1 \%$ of US income earners receives no less than $18 \%$ of all incomes and, what is even more surprising, the top $0.1 \%$ of earners receives $11 \%$ of all incomes. In other words, the top $1 \%$ of US income earners is nearly 20 times as rich as the other $99 \%$ and the top one tenth of $1 \%$ is even more than one hundred times richer than the remaining $99.9 \%$. This glaring inequality had developed more or less constantly over time and peaked around 2007 but, historically quite unusually, has not declined much during the recent US depression and since 2009.

In distribution terms, Austria is the very opposite of the USA. The income distribution of Austrian wage earners is one of he most equal anywhere, although little is known (typically!) about the relative incomes of the self-employed, particularly in the financial sector. Consequently, Austrian banks are taxed on an uncertain basis. The largest privately owned

\footnotetext{
34 Greenspan 2007, 392, note.

35 The Economist, March 4, 2014, 10.
} 
bank, Erste Österreichische AG, happens to be the most highly taxed bank in the world, taxed at present up to $90 \%$ of its net income. In contrast, in the USA a highly unequal income distribution and (in this depression typical) the strong political favouring of banks and "bankers" - as well as the opposite on both counts in other countries - go hand in hand, as one would surmise when political power goes with the banking industry as now in the USA.

\section{XIII}

National income data still substantially underscore in particular the economic problems of the USA. Even on these terms the USA are now no longer, and by a wide margin, the per capita richest nation in the world. According to the statistical estimates of The Economist's "The World in 2014", the USA with a nominal GDP per head of $\$ 54.920$ and a real one in purchasing power terms of the same $\$ 54.920$, have fallen behind Norway with nearly twice their nominal income. In real PPP terms Norway is also about one third richer (GDP per head \$103.950, in PPP terms $\$ 70.250)$. Second comes Switzerland, mainly nominally, but only $2 \%$ richer than the USA in real terms (\$73.070, in PPP terms \$55.720). Singapore is third, but only in nominal income, its real income per head being below the US level (GDP per head \$55.930, in PPP terms \$49.280). Qatar is not given in this statistic. Interestingly enough for us Austrians, Austria comes fifth on PPP terms, being outdistanced by Hong-Kong, but only in real terms (GDP per head \$42.140, in PPP terms \$56.240; Austria \$48.260, in PPP terms \$45.340). Per head of the population, the USA are about $12 \%$ richer nominally than Austria, about $20 \%$ in PPP terms. Denmark, Finland (very slightly), Sweden, and Canada outdistance Austria only in nominal terms, but not in real PPP terms. Sweden is next to Austria and only very slightly lower in PPP terms.

The most important problem in real national income comparisons, however, arises from the international national income conventions, which have become more and more problematic, and especially so during the $21^{\text {st }}$ century. (I shall write "national income" or "national product" as it should best be measured, but actually it is not so because of contrary international conventions.)

By far the greatest problem is actually very little known: National income figures are calculated ac- cording to invoices dispatched by economic agents (individuals and firms), not according to bills paid! If a bill is not paid within the accounting year, that year's GDP should be corrected for this; but one is not very sure that statisticians will actually do so. Within and between developed economies bills are supposed to be paid within three months or half a year. But the first (much smaller) problem arises with the decay of payments habits: many people no longer pay on time, during periods of depressive business, as recently. One cannot be sure that the probabilities of payment are not overestimated both by the firms and by statisticians - in order to let economic developments appear rosier than they are. Remember that above all national income statistics do not include backward corrections once they exceed a period of one year. But the real (real in both senses!) problem arises with the backward correction of longer-term capital values; and in practice this means above all sales values of houses bought on credit - credit that turns out not to be repaid. In 2003-2007 for the first time the USA granted both much too easy credit terms, crediting up to $100 \%$ of purchase prices (including sales fees); and above all credits were granted for highly dubious purchases. Therefore, as I quoted in section VIII, Greenspan estimated that uncollectible real estate debts in the USA were up to $\$ 17$ "trillion" or about $120 \%$ of GDP; and if all that was not accounted for in GDP calculation it would mean that for the entire first decade of the $21^{\text {st }}$ century US GDP was overestimated by some $8 \%$ a year. If we take only about $60 \%$ of this estimation of Greenspan's as an actually realised loss and then lower the figure to about $80 \%$ of it for what might have found its way into GDP statistics, this would still amount to a loss of about $4 \%$ a year. In consequence, already this one correction would reduce the at best $2.5 \%$ annual growth rate of US national income to actually $-1.5 \%$ (by another calculation even to $-5 \%$ ) for every year in that first decade, turning the USA into a steadily shrinking economy.

A second correction must be made for US national income accounting only, though not for the usual international statistics for the USA: Against binding international, i.e. UN, statistical conventions the USA calculate their "national income" not according to gross domestic product values but according to gross national product values: They leave out (ignore) - above all - all increasing running foreign US 
debts. Even in GDP terms, The Economist estimates ${ }^{36}$ US GDP growth at $+2.6 \%$, too optimistically I think. As debts increase in the USA by $2.4 \%$ annually according to these Economist statistics, that would mean that at present the USA achieve something like zero income growth as soon as one subtracts the increasing debts. Or at best a net growth rate of a meagre $0.6 \%$ if one relies on The Economist of March 8, 2014, which quotes a present $2.8 \%$ growth rate and a $-2.2 \%$ current account balance (i.e. increasing debts). In most years of the $21^{\text {st }}$ century increasing debt meant that even without a crisis the USA had a net income growth of only -0.5 or even $-1.0 \%$ a year. And this would still have to be corrected, as before, for unpaid bills.

Much more important is a third correction, now of "gross national product" more appropriately calculated: The world suffers damages due to storms, floods, droughts, etc. This type of damages has obviously increased of late, due to climate change. As yet, such damages have never been subtracted from social product, while activities of repairing the damages are added to it. Realistically, on capital account we would have to subtract the damages and the increasingly larger losses due to them.

We might include the above named damages under environmental ones in a wider sense or we could consider environmental damages as a separate fourth category. Humans consume more and more irreplaceable environmental assets and pollute their environment. The negative effects of these activities are not taken into account in GDP calculations. What is taken into account are the costs of e.g. cleaning up environmental pollution. If - this would be the fourth correction needed - in the first place the negative effects were taken into account such environmental damages - increasing over time, to boot - would substantially lower actual income gains, often to zero and below.

The most important difficulty, the fifth and final one in our survey, is that national income statistics are calculated on the assumption that relative prices of the various items stay constant over time. But what if important items, especially those with low price elasticities, i.e. items not easily substituted, steadily rise in price? Such a rise in supply price will be typical for items that become scarcer due to their partial

36 "The World in 2014", p.97. exhaustion or to increasing limitations of their physical supply conditions worldwide. This is the problem that has - unfortunately - been overdramatized by environmentalists, who see world supply as easily exhaustible, while economists have pointed out on the one hand the usual economic remedy of finding substitutes and, on the other hand, the demand-reducing effect of rising prices, i.e. the price elasticity of demand.

But what if there are no substitutes and price elasticity of demand is also very low in absolute terms? This is the case for two central categories of consumption: food and energy, including transportation cost. According to The Economist ${ }^{37}$ the dollar index for food prices with $2005=100$ is now at 200.1, in other words: food costs have doubled (!) over the last eight years. And the West Texas Intermediate price of a barrel of oil is now \$103.2, up from only $\$ 11$ about fifteen or twenty years ago: it has increased nine-fold. If the increase of food prices since 2005 were to continue unabated, food prices around 2050 - at the expected peak of world population - would be about 40 times higher than now. For Austria, where the food share of average income consumption is about $12.5 \%$ at present, this share could easily rise to $37.5 \%$ of national income. Energy prices will continue to rise, but are impossible to calculate or predict. But it is not unrealistic to assume that the energy share of national income will at least double. Not very much would be left for other consumption then. We are clearly heading towards real impoverishment in the developed world, not towards real income growth, as optimists would have it. About 2005 the developed economies had reached the maximum of real income per capita; we are already on a long-run downward path.

\section{XIV}

I started out this paper as both a theoretical and also practically active economist, both with a mean and a variance perspective, both with a view of singling out the first and singling out the second moment of empirical probability distributions: as one who needs the viewpoint of the theoretical economist and also that of the practising statistician. As to probability distributions assumed one has to think especially of changing probability distributions, changing both in their means and in their variances. Apart from God there is nothing absolute in this world, everything is

37 The Economist, March 4, 2014, p.77. 
in principle relative and (above all as a didactic simplification) true only for a short time. I have been a moderate Keynesian and a moderate Free Market economist, of late usually, but wrongly, called a neoclassical one. But I have changed my viewpoint often, and rightly so. In 2011, Nicholas Wapshott, a journalist, published a book Keynes - Hayek: The Clash that defined Modern Economics. ${ }^{38}$ Apart from the questions "Which Keynes?" and "Which Hayek?" both of these giants of economic thought were quite variable and not always in conflict. But one has to ask: Are these two authors of modern economics? Keynes died in 1946, i.e. close to seventy years ago, while Hayek died at a ripe old age in $1992 .{ }^{39}$ Both were theorists of closed economies, and those are largely irrelevant nowadays for a globally integrated economy, especially one like Austria where the export share in gross national product is some 56 or $57 \%$. Keynes' basic idea was that highly variable and uncertain shortrun economic expectations matter greatly, which is true for financial markets - and those were one of his main subjects. This is relevant in highly uncertain periods of recessionary or depressive economies as once more in recent, but already outdated periods. Hayek mainly thought of collective expectations formation centred on innovation, of collective expectations when general economic development is not too uncertain. So their views are complementary rather than fully contradictory and may be used either alternatively over time or even along each other. But apart from the difficulty of international determination the real problem with their views is their use with the heterogeneity of so many different groups of economic actors. How can we use such simplified models of one or two groups for the clash between various types of Republicans and even more various types of Democrats in the present-day USA, or for the dominance of pensioners of 64 to 50 years of age and younger (!) as in Austria?

Once more, I return to The Economist, this time to a recent review of a book by Eswar Prasad, The Dollar Trap. Prasad asserts that the dollar's position is "suboptimal but stable and self-reinforcing". The urgent question is what will happen to this highly unstable dollar in the longer run. The position of the dollar's counterpart, the yuan, is much clearer, but often forgotten: "The yuan has appreciated by about 35\% against the dollar since mid-2005". The really interesting point of Prasad's seems to be that the strength of the dollar is in a sense a self-contradictory notion: International economic agents tend to hold dollars, in spite of making constant losses in them, because they can use the dollar as a hedge in especially strong crises: "The dollar has no long-term tendency to strengthen ... the dollar tends to strengthen in times of crisis ... in times of stress, the appeal of a dollar asset is that it always holds its value against a dollar debt. The dollar is a global hegemon partly because it is also a global hedge." 40

Such a book is a novelty and relevant for financial market actors. The real problems arise between contradictory situations of the present and of the future, contradictory aims of those who hold both financial asset and financial debt positions in the same currency, and the contradictory developments of the real and the financial economy. This makes recurring analysis of quantitative economic development a necessity, an ever topical challenge requiring an open, unbiased, and, dare I say it, youthful mind. In many ways our present problems are so new and also defy any kind of easily simplified homogenous view that we are forced to use a kind of theoretically informed historicism to come to terms with the challenges of our unordered economic world..$^{41}$

40 The Economist, March 4, 2014, 65: review of Eswar S.Prasad, The Dollar Trap: How the U.S.Dollar Tightened Its Grip On Global Finance. 2013. Quotations taken from the review.

41 For an early evaluation along these lines see already Robert A. Mundell, "A Reconsideration of the Twentieth Century", Nobel Lecture, American Economic Review, 90/3, 2000, 327-340.

38 Nicholas Wapshott, Keynes Hayek - The Clash That Defined Modern Economics. New York - London 2011.

39 See Erich W.Streissler, "Hayek on Information and Socialism", Wirtschaftspolitische Blätter 1992/2, 258-283. 